
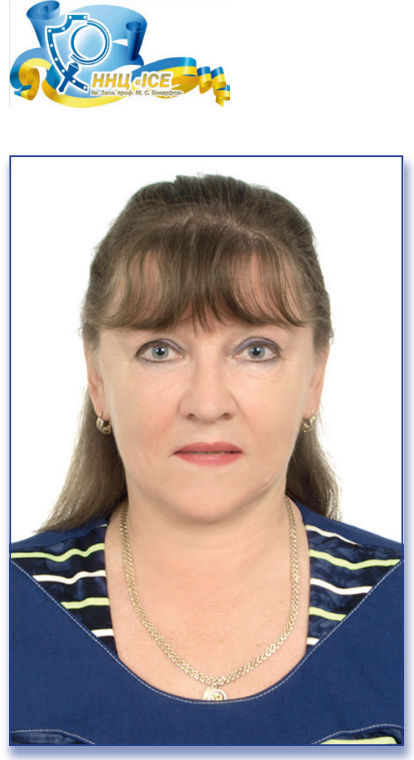

Petrova

Iryna

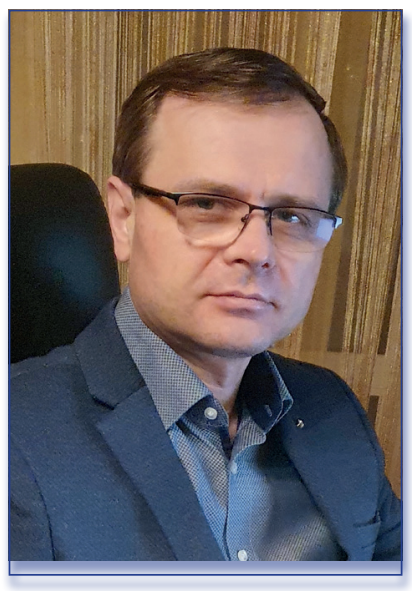

Kurdes

Oleg
Peculiarities of Training and Advanced Training

of Fingerprint Experts

DOI: https://doi.org/10.32353/acfs.3.2021.07

UDC: 343.98

Iryna Petrova,

Doctor of Law, Professor, Principal Researcher of R\&D and Publishing Laboratory at National

Scientific Centre "Hon. Prof. M. S. Bokarius Forensic Science Institute" Kharkiv, Ukraine

ORCID: https://orcid.org/0000-0002-1652-6715

e-mail: ekobezpeka.ira@gmail.com

Oleg Kurdes,

Postgraduate Student, Researcher of Advanced Training Department at National Scientific

Centre "Hon. Prof. M. S. Bokarius Forensic Science Institute" Kharkiv, Ukraine

ORCID: https://orcid.org/0000-0003-2736-4616

e-mail: oleg700615@ukr.net

\section{Peculiarities of Training and Advanced Training of Fingerprint Experts}

The Article purpose is identification of shortcomings in training, retraining and advanced training of fingerprint experts as well as outline of scientific basis for improving this area of activity. The analysis of domestic scientists' developments has made it possible to establish that in Ukraine there is no single unified regulatory legal act governing training, retraining and advanced training of a forensic expert, regardless of his institutional subordination.

It is proved that current regulatory legal framework for professional training of forensic experts, in particular fingerprint experts, of the system of the Ministry of Justice of Ukraine is at the stage of formation and development and requires further reformation. It is necessary to highlight the section: Procedure for specialists' training and internship in the Regulations on the Central Expert Qualification Commission under the Ministry of Justice of Ukraine and Certification of Forensic Experts, and to develop a separate regulatory legal act regarding the procedure for advanced training on its basis.

Keywords Keywords: fingerprint expert, fingerprint analysis, training, retraining, advanced training, regulatory legal acts.

Formulation of Research Problem. Current criminal, administrative, economic, and civil proceedings are impossible without the usage of the latest advances in science and technology, in other words, without special knowledge. The improvement of this knowledge promotes the development of forensic science as the main procedural form of its use. Expert research, in criminal proceedings, contains not only provisions of technical and natural sciences, but also legal, as it is directly related to procedural norms, features of forensic researches, etc.

Considering issues of fingerprint analysis in court proceedings, it should be noted that a forensic fingerprint expert must have not only knowledge of basic sciences, but also substantiated legal knowledge, know the current methods of this expert research. It should be emphasized that the training of a forensic expert is a complex process, which involves not only the study of theoretical material and obtaining practical skills, but also the formation of the expert way of thinking. If theoretical knowledge can be mastered in a short period of time, then practical skills are formed over a long period of time. It should also be noted that the formation of the expert way of thinking also takes a lot of time. Therefore, becoming the fingerprint expert is a long-time process, and his training should be constant. 
The lack of modern standardized forensic methods for fingerprint analysis and obsolescence of existing methods has a negative impact on the preparation of new addition of fingerprint experts, which requires immediate elimination of this gap. Moreover, the whole system of fingerprint experts training, especially their practical training, need to be rethought. It is urgent to address the introduction of psychological training as a means of formation of the expert way of thinking and psychological resilience of the expert to stressful situations in practice.

Analysis of Essential Researches and Publications. Issues of training, retraining and advanced training of forensic experts were considered in the works by O. M. Kliuiev, I. A. Petrova, O. P. Snigerov, N. M. Tkachenko, S. He. Hasparian, O. V. Solovei, and other scientists. These scientists have made a great contribution to the development of strategic areas of staffing of forensic institutions. The problematic issues of the current state of training, retraining, and advanced trainings of forensic experts were raised by them. However, at present there is an urgent need to specify ways to improve this area of activity, taking into account the achievements of science and technology to meet the needs of law enforcement agencies and the court in the qualitative conclusions of forensic experts. Moreover, issues of training, retraining and advanced training of forensic experts of certain categories in the areas of expert specialties has not been fully studied in Ukraine.

The Article Purpose is to uncover drawbacks during training, retraining, and advanced training of fingerprint experts, outline the scientific basis for improving this area of activity. The given research is one of the few attempts in Ukraine to identify gaps in the training, retraining, and advanced training of forensic experts of the certain categories in the area of expert specialty, namely fingerprint experts, and outline specific ways to improve their training.

Main Content Presentation. It should be noted that considering the history of origin and use in the process of revealing, detection, investigation of offenses in forensic science, one of the first is the doctrine of human handprints, which was called "fingerprinting". Fingerprinting is interpreted in the field of forensic science, which allows you to examine the configuration of whorl patterns on the palmar surface of the hands and feet of people to establish identity.

OIn addition, this research can establish circumstances of the offense: an approximate age of the person who left fingerprints; which hand left traces, what are the features of human hands; which areas of palm surface left traces; what is the term of preservation of handprints, etc., as well as to identify the offender and other persons involved in the offense.

The aforementioned indicates that fingerprint analysis has always been and will be highly demanded in the practice of law enforcement agencies and courts. The outcome of criminal proceedings largely depends on the execution of instructions of the pre-trial investigation bodies and court in terms of conducting fingerprint analysis. Scientists emphasize that the effectiveness of the fingerprint analysis is influenced by many factors:

- - quality of research objects and comparative samples;

- - availability of modern equipment;

- - timely updating of methods for conducting fingerprint analysis;

- - proper professional trainings of experts;

- $\quad$-state of filling the relevant databases used by experts during the fingerprint analyses. ${ }^{1}$

\footnotetext{
Сухомлин Т. В., Юрчик Т. В. Судово-дактилоскопічна експертиза у кримінальному провадженні. Збірник наукових праць Харківського національного педагогічного університету імені Г. С. Сковороди. Харків. «ПРАВО». Випуск 30, 2019 р. С. 104-109.
}

\section{Petrova, O. Kurdes}

PECULIARITIES OF TRAINING AND ADVANCED TRAINING OF FINGERPRINT EXPERTS

The Article purpose is identification of shortcomings in training, retraining and advanced training of fingerprint experts as well as outline of scientific basis for improving this area of activity. The analysis of domestic scientists developments has made it possible to establish that in Ukraine there is no single unified regulatory legal act governing training, retraining and advanced training of a forensic expert, regardless of his institutional subordination.

It is proved that current regulatory legal framework for professional training of forensic experts, in particular fingerprint experts, of the system of the Ministry of Justice of Ukraine is at the stage of formation and development and requires further reformation. It is necessary to highlight the section: Procedure for specialists' training and internship in the Regulations on the Central Expert Qualification Commission under the Ministry of Justice of Ukraine and Certification of Forensic Experts, and to develop a separate regulatory legal act regarding the procedure for advanced training on its basis.

Particular attention is drawn to the absence of guidelines on the organization of the education process while forensic expert training, negatively affecting the process of learning during onsite training (in forensic science institutions). Expediency of the development of guidelines on forensic experts' training for each individual expert specialization is established, which are suggested to be added as separate $R \& D$ topics to research work plan of the Ministry of Justice of Ukraine. It is indicated that a detailed study of the introduction of such a component as mentoring into the system of forensic experts' training is essential.

It is stressed that development of the regulatory legal framework for training forensic experts abroad in corresponding forensic science institutions, and the coordination of this area of activity by the Ministry will have a positive impact not only on the quality of training but also on the acquisition of world experience with the subsequent possibility of improving methods for conducting fingerprint analyses. 


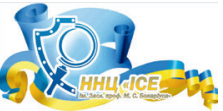

Keywords: fingerprint expert, fingerprint analysis, training, retraining, advanced training, regulatory legal acts.

\section{I. А. Петрова, О. В. Курдес}

ОСОБЛИВОСТІ ПІДГОТОВКИ ТА ПІДВИЩЕННЯ КВАЛІФІКАЦІЇ ЕКСПЕРТІВ-ДАКТИЛОСКОПІСТІВ

Метою статті є виявлення недоліків під час підготовки, перепідготовки та підвищення кваліфікації експертів-дактилоскопістів, окреслення наукових засад удосконалення цього напряму діяльності. Аналіз напрацювань вітчизняних учених дозволив установити, що єдиного уніфікованого нормативно-правового акта, котрий регулює підготовку, перепідготовку та підвищення кваліфікації судового експерта, незалежно від його відомчої підпорядкованості, в Україні не існує.

Доведено, що діюча нормативно-правова база професійної підготовки судово-експертних кадрів, зокрема й експертів-дактилокопістів, системи Міністерства юстиції України перебуває на стадії становлення та розвитку й потребує подальшого реформування. Уважаємо за необхідне виокремити із Положення про Центральну експертно-кваліфікаційну комісію при Міністерстві юстиції України та атестацію судових експертів розділ «Порядок підготовки та стажування фахівців» і розробити на його основі окремий нормативно-правовий акт щодо порядку проведення професійної підготовки.

Особливу увагу приділено питанню відсутності методичних рекомендацій щодо організації навчального процесу підготовки судового експерта, що негативно впливає на процес навчання безпосередньо на місцях (у судово-експертних установах). Установлено доцільність розроблення методичних рекомендацій із підготовки судових експертів за кожною окремою експертною спеціальністю, що слід додати, як окремі теми НДР, до плану науково-дослідних робіт Міністерства юстиції України. Констатовано, що детального дослідження потребує визначення необхідності впровадження в систему підготовки судово-експертних кадрів такої складової, як наставництво.
Peculiarities of Training and Advanced Training

of Fingerprint Experts

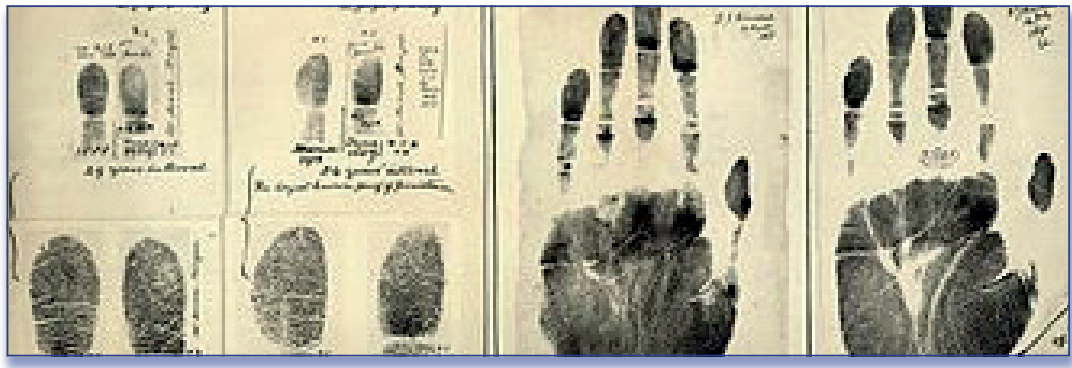

Figure 1. Palms prints with whorl patterns

Going along with the above factors, that have an impact on the effectiveness of this type analysis, we will consider the issue of proper training of the forensic expert. By today, the fingerprint expert has more opportunities for the quality analysis than, for example, it was thirty years ago. The emergence of new devices and chemical reagents were of progressive importance for the development of fingerprinting in general. Forensic experts, conducting fingerprint analyses, must not only have a basic knowledge of the natural sciences, but also be sufficiently knowledgeable in the field of jurisprudence, namely forensics.

General requirements for the forensic expert are enshrined in law and set out in Article 10 of the Law of Ukraine On Forensic Examination. According to the current legislation, forensic experts can be persons who have necessary knowledge to provide the conclusion on the issues under investigation. Forensic experts of state specialized institutions may be specialists who have the appropriate higher education, educational and qualification level not lower than a specialist, have been trained and qualified as a forensic expert in a particular specialty. ${ }^{2}$

That is, the legislator imposes a number of requirements to the forensic expert, who works in a state specialized institution for forensic examinations, including the fingerprint analysis, namely:

1) availability of the appropriate higher education and educational qualification level not lower than a specialist;

2) undergoing appropriate training in state specialized institutions;

3) certification and qualification of a forensic expert in a certain specialty.

It is worth noting the statement by $N$. M. Tkachenko that training of forensic experts is one of the most important means of expert support of justice in the state, as only a specialist of high scientific level is able to provide an objective conclusion based on the use of specialized knowledge ${ }^{3}$.

חS. He. Hasparian's position on improving the training of forensic experts is convincing. Thus, she emphasizes that the dynamic development of forensic science in Ukraine, the introduction of new technologies in the practice of forensic institution of the Ministry of Justice of Ukraine, as well as increasing needs for quality of forensic examinations determine the urgency of improving the training of highly qualified scientific personnel for the needs of forensic activities ${ }^{4}$. Additionally, she notes that in the legal regulation of staffing of forensic institutions, administrative legislation occupies a

\footnotetext{
Про судову експертизу : Закон України від 25.02.1994 р. № 4038-XII (зі змінами та доповненнями). Відомості Верховної Ради України (ВВР). 1994. № 28. URL: https:/ / zakon.rada. gov.ua/laws/show/4038-12 (дата звернення 07.05.2021)

Ткаченко Н. М. Удосконалення професійної підготовки судового експерта - важливий фактор розвитку експертної дидактики. Теорія та практика судової експертизи $i$ криміналістики : зб. наук. праць. Ха рків : Право, 2018. Вип. 18. С. 203. DOI https://doi. org/10.32353/khrife.2018.22

4 Гаспарян С. Г. Шляхи підвищення якості підготовки кадрів для судово-експертних установ Міністерства юстиції України. Теорія та практика судової експертизи і криміналістики : зб. наук. праць. Харків : Право, 2018. Вип. 18. С. 281. DOI https:/ / doi.org/10.32353/khrife.2018.30
} 
prominent place and purposes to improve the field of professional training of forensic experts ${ }^{5}$.

The proposal by O. V. Solovei on the expediency of creating a single non-departmental body of forensic activity for quality training of staffing with relevant diplomas and certificates of forensic expert requires detailed consideration ${ }^{6}$. We have previously stressed that the issue of training and retraining of forensic experts is quite complex and requires a separate, comprehensive and thorough study, but the scientific component, which combines exploratory, analytical and synthesizing components, should be present in the daily activities of the expert, his professional development ${ }^{7}$.

Taking into account works of domestic scientists, it should be noted that in Ukraine there is no single unified legal act regulating the training, retraining, and advanced training of forensic expert, regardless of his departmental subordination. In accordance with Article 8 of the Law of Ukraine On Forensic Examination, the organization of scientific and methodological support of forensic activities and organizational and managerial principles of state specialized institutions are entrusted to ministries and other central executive bodies, the management of which includes state specialized institutions ${ }^{8}$. Thus, the legislator imposes the obligation to organize the process of training experts on ministries and other central executive bodies. According to Article 7 of the Law of Ukraine On Forensic Examination, state specialized institutions include:

- research institutions of forensic examinations of the Ministry of Justice of Ukraine;

- research institutions of forensic examinations, forensic and forensic psychiatric institutions of the Ministry of Healthcare of Ukraine;

- expert services of the Ministry of Internal Affairs of Ukraine, the Ministry of Defense of Ukraine, the Security

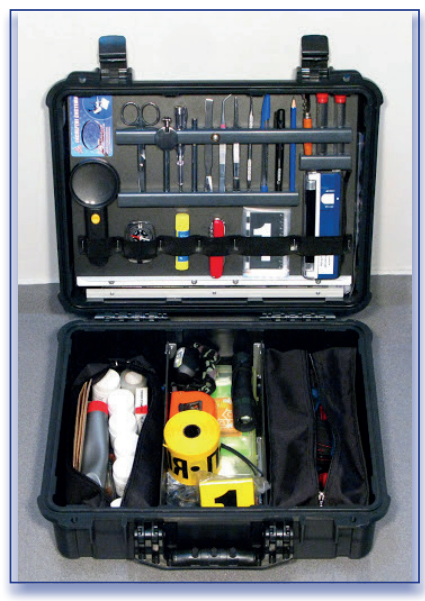
Service of Ukraine and the State Border Guard Service of Ukraine ${ }^{9}$.

It should be noted that each ministry and department organize the training of specialists in the field of forensic science differently. The functioning of the faculties of training of criminologists and forensic experts in the institutions of higher education of the Ministry of Internal Affairs of Ukraine deserves attention. Upon graduation, graduates receive a diploma of higher education and a special admission to the right to conduct forensic examinations.

Figure 2. Expert's versatile case for inspection of the scene $\ddot{i}$

Гаспарян С. Г. Місце адміністративно-правових норм у правовому регулюванні кадрового забезпечення судово-експертних установ України. Теорія та практика судової експертизи i криміналістики: зб. наук. праць. Харків: Право, 2019. Вип. 20. С. 185. DOI https://doi. org/10.32353/khrife.2.2019.13

6 Соловей О.В.Особливості професійної підготовки працівників експертної служби Міністерства внутрішніх справ України. Теорія та практика судової експертизи $i$ криміналістики : зб. наук. праць. Харків: Право, 2019. Вип. 20. С. 236. DOI https://doi. org/10.32353/khrife.2.2019.17

Петрова І. А., Снігерьов О. П. Формування особистості сучасного судового експерта. Теорія та практика судової експертизи і криміналістики : зб. наук. праць. Харків: Право, 2017. Вип. 17. C. 168. DOI https://doi.org/10.32353/khrife.2017.20

8 Про судову експертизу : Закон України від 25.02.1994 р. № 4038-XII (зі змінами та доповненнями). Відомості Верховної Ради України. 1994. № 28. URL: https://zakon.rada.gov. ua/laws/show/4038-12 (дата звернення 07.01.2021).

Там само

Акцентовано,

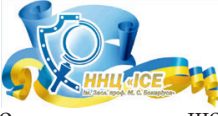

вдосконалення

нормативноправового регулювання проходження навчання експертів за кордоном у відповідних експертних установах координація даного напряму діяльності Міністерством позитивно впливатиме не лише на якість навчання, але й на набуття світового досвіду 3 подальшою можливістю вдосконалення методик проведення дактилоскопічних експертиз.

Ключові слова: експерт-дактилоскопіст, дактилоскопічна експертиза, підготовка, перепідготовка, підвищення кваліфікації, нормативно-правові акти.

\section{Petrova, O. Kurdes}

BESONDERHEITEN

DER AUSBILDUNG

UND ERHÖHUNG

DER QUALIFIKATION

VON EXPERTEN-

DAKTYLOSKOPISTEN

Das Ziel des Artikels ist es, die Ausbildung, Weiterbildung, Erhöhung der Qualifikation von daktyloskopischen Experten zu bemängeln und wissenschaftliche Grundlagen für die Verbesserung dieses Tätigkeitsbereichs darzulegen. Die Analyse der Leistungen einheimischer Wissenschaftler ergab, dass es in der Ukraine keinen einheitlichen normativen Rechtsakt gibt, der die Ausbildung, Weiterbildung, Erhöhung der Qualifikation vom Forensiker unabhängig von seiner behördlichen Unterstellung regelt.

Es ist bewiesen, dass der jetzige Rechtsrahmen für die Berufsausbildung von Forensikern u. a. Experten-Daktyloskopisten im System des Justizministeriums der Ukraine nur entsteht, sich entwickelt und weitere Reformierung braucht. Wir halten es für notwendig, den Abschnitt «Verfahren zur Ausbildung und zum Praktikum von Spezialisten» von der Vorschrift über die Zentrale Expertenqualifikationsko mmission des Justizministeriums der Ukraine und die Attestation von Forensikern $\mathrm{zu}$ trennen und ausweislich dieses Abschnitts einen besonderen normativen Rechtsakt für das Verfahren zur Berufsausbildung zu entwickeln.

Es wurde auf das Fehlen von methodischen Empfehlungen zur Organisation des A u s bildung s prozesses für die Ausbildung eines Forensikers geachtet, was 
Peculiarities of Training and Advanced Training

of Fingerprint Experts

negativ den Lernprozess direkt vor Ort (in forensischen Institutionen) beeinflusst. Es wurde festgestellt, dass es zweckdienlich ist, methodische Empfehlungen zur Ausbildung von Forensikern in jeder einzelnen Expertenfachrichtung zu entwickeln, die als separate Forschungsthemen zum Forschungsplan des Justizministeriums der Ukraine hinzugefügt werden sollten. Es wird bestimmt, dass die Feststellung der Notwendigkeit zur Einführung eines Meisters im System der Ausbildung vom forensischen Personal eine detaillierte Untersuchung braucht.

Es wird betont, dass die Verbesserung der normativen Rechtsregelung für die Ausbildung von Experten im Ausland in geeigneten Experteninstitutionen und die Koordinierung dieses Tätigkeitsbereichs durch das Ministerium positiv nicht nur auf die Qualität der Ausbildung, sondern auch auf die Erwerbung internationaler Erfahrungen mit weiteren Möglichkeiten zur Verbesserung der Methodiken zur Durchführung von daktyloskopischen Expertisen Einfluss nimmt.

Schlüsselwörter: Experte-

Daktyloskopist, daktyloskopische

Expertise,

Weiterbildung, Erhöhung

Ausbildung

Rechtsakte.

\section{Petrova, O. Kurdes}

CARACTÉRISTIQUES

DE FORMATION ET

D'AMÉLIORATION DE

LA QUALIFICATION DES

DACTYLOSCOPISTES

Le but de l'article est d'identifier les lacunes dans la formation, le recyclage et la formation avancée des experts en dactyloscopie, en soulignant les bases scientifiques pour améliorer ce domaine d'activité. L'analyse des réalisations des scientifiques nationaux a révélé qu'il n'y a pas d'acte juridique unifié unique qui réglemente la formation, le recyclage et la formation avancée d'un expert médico-légal, quelle que soit sa subordination départementale, en Ukraine.

Il est prouvé que le cadre juridique actuel pour la formation professionnelle des experts médico-légaux y compris les dactyloscopistes, le système du ministère de la Justice de l’Ukraine
The training of forensic experts of the Ministry of Justice of Ukraine is regulated by a number of normative legal acts, namely: the Law of Ukraine On Forensic examination; Regulations on attestation of researchers approved by the Resolution of the Cabinet of Ministers of Ukraine No.1475 dated on August 13, 1999; Regulations on the Central Expert Qualification Commission (hereinafter referred to as CEQC) under the Ministry of Justice of Ukraine and certification of forensic experts approved by the Order No. 301/5 of the Ministry of Justice of Ukraine dated on March 3, 2015; The procedure for assigning qualification classes of forensic experts to employees of forensic research institutions of the Ministry of Justice of Ukraine approved by the Order No. 3660/5 of the Ministry of Justice of Ukraine dated on December 30, 2011, etc.

Regulations on the Central Expert Qualification Commission under the Ministry of Justice of Ukraine and certification of forensic experts determines the procedure for training and internship of specialists who intend to obtain or confirm the qualification of a forensic expert and the procedure for attestation in order to assign and confirm the qualification of the forensic expert in the specified commission ${ }^{10}$. It should be noted that the training and retraining of forensic experts in the system of the Ministry of Justice of Ukraine is determined not by a separate system legal act, but only by one section of the Regulations on the Expert Qualification Commission under the Ministry of Justice of Ukraine and attestation of forensic experts. (Section III. Procedure for training and internship of specialists who intend to obtain or confirm the qualification of the forensic expert), which is insufficient for the full training, retraining and advanced training of forensic experts.

According to Regulation on the Central Expert Qualification Commission of the Ministry of Justice of Ukraine and attestation of forensic experts while resolving by the CEQC Chamber on the compliance of the higher education with the expert specialty, in which the person intends to obtain the qualification of the forensic expert, the study time in the relevant disciplines specified in the diploma supplement ${ }^{11}$. Отже, подібний підхід до вирішення питання щодо відповідності наявноїTherefore, such an approach to resolving the issue of compliance of existing higher education with the expert specialty is subjective and should be regulated by a separate legal act.

The main condition for hiring a fingerprint expert is the availability of higher legal education. At the same time, V. O. Komaha and his colleagues note that in modern higher education institutions of Ukraine that train lawyers, the curriculum of criminalistics and forensic science has not changed for some time and the issues of forensic science are given too little attention. Scientists have come to the conclusion that the contribution of university science to the practice of forensic researches is unsatisfactory ${ }^{12}$. Учені, дійшли висновку, що внесок вузівської науки в практику судовоекспертних досліджень незадовільний ${ }^{13}$. It should be emphasized that the number of hours devoted to the study of such a discipline as Criminalistics in higher education is constantly decreasing, which also does not contribute to the formation of the basic principles of a lawyer. This situation deepens the problem of the level of knowledge of the person who intends to obtain the

\footnotetext{
10 Про затвердження Положення про Центральну експертно-кваліфікаційну комісію при Міністерстві юстиції України та атестацію судових експертів : Наказ Міністерства юстиції України від 03.03.2015 № 301/5. URL: https://zakon.rada.gov.ua/laws/card/z0249-15 (дата звернення 07.05.2021).

11 Там само

12 Комаха В. О., Стрілець Г. О., Чернобай Л. М. Актуальні аспекти стосовно кадрової підготовки судових експертів в Україні. Експертне забезпечення правосуддя:матер. міжнар. наук.-практ. конф. Сімферополь. КримНДІСЕ. 2006. С. 293.

13 Там само. С. 294.
} 
qualification of the forensic expert in trace evidence analysis in the specialty Fingerprint Analysis.

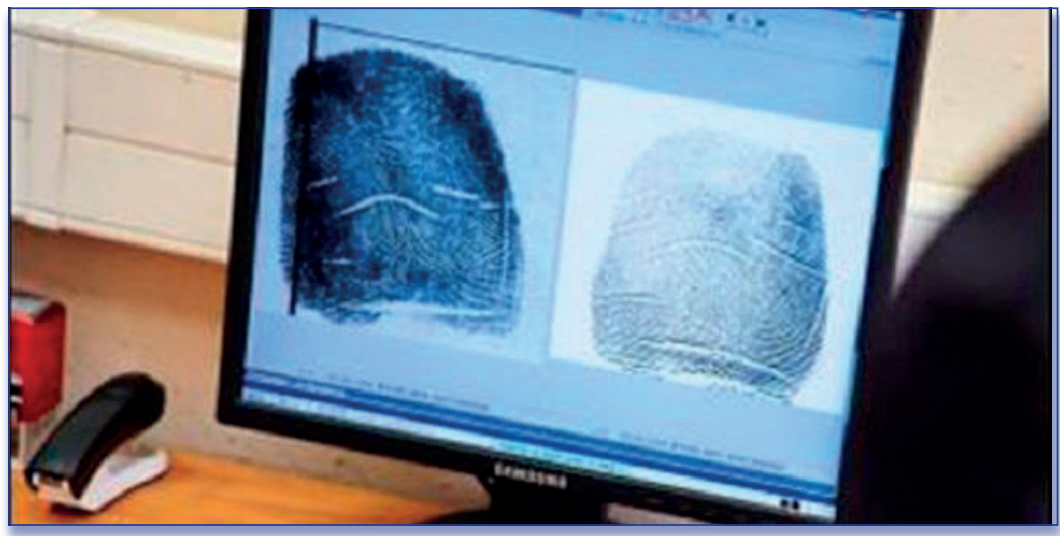

Figure 3. Fingerprint on a computer

The method of fingerprint analysis provides for the use of the following methods: physical, chemical, physico-chemical, microbiological ${ }^{14}$. It means that the fingerprint expert must also have knowledge in the fields of physics, chemistry and biology. These disciplines are not included in the training program for lawyers. Therefore, it is proposed to carefully analyze the certificate of secondary education of a candidate for the position and hire a well-considered decision on his / her ability to conduct high-quality fingerprint analyses during the recruitment of the fingerprint expert.

It is necessary to emphasize the lack of guidelines for the organization of the educational process of training the forensic expert, which negatively affects the training directly on the ground (in forensic institutions). We consider it expedient to develop guidelines for the training of forensic experts in each separate expert specialty and to add this issue, as separate RED topics, to the research and development plan of the Ministry of Justice of Ukraine.

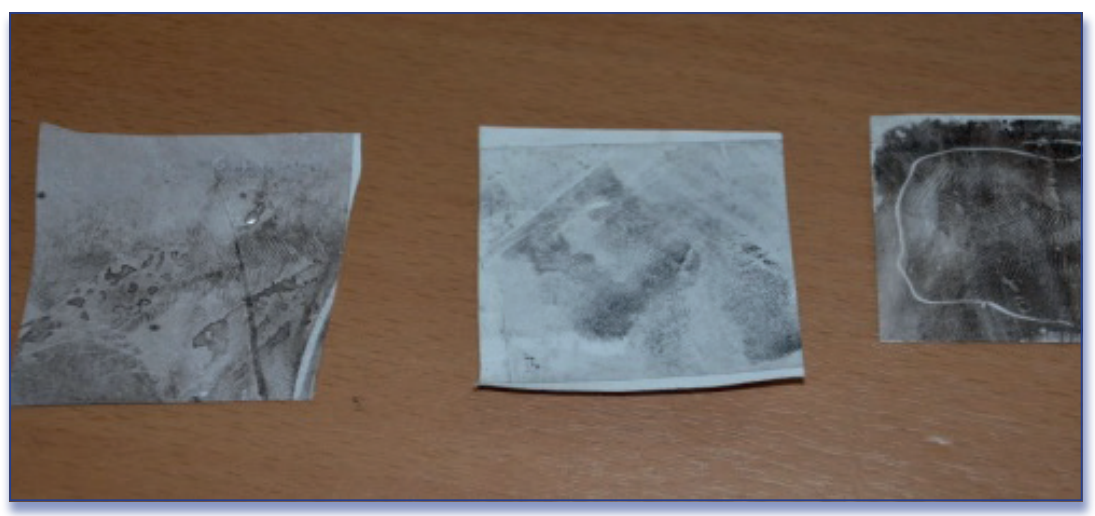

Figure 4. Fingerprints

M. Ye. Bondar, during the study of the problem of improving the professional training of a handwriting expert, which may well relate to the

14 Методика дактилоскопічної експертизи. Експертна спеціальність 4.6 «Дактилоскопічні дослідження» / [укл. Жолтанська І. І., Кузнєцов В. А., Щавелєв А. В., Димитрова Ю. В., Кушніренко Н. В.]. К. : ДНДЕКЦ МВС України, 2014. С. 11. est au stade de la formation et du développement et doit encore être réformé. Nous estimons qu'il est nécessaire de séparer la section "Procédure de formation et de stage des spécialistes" du Règlement sur la Commission centrale de qualification des experts au Ministère de la justice de l'Ukraine et la certification des experts légistes et d'élaborer un acte juridique distinct sur la procédure de formation.

Une attention particulière a été accordée au manque de lignes directrices pour l'organisation $\mathrm{du}$ processus éducatif de formation d'un expert médico-légal, ce qui affecte négativement le processus d'apprentissage directement sur le terrain (dans les institutions médico-légales). L'opportunité d'élaborer des recommandations méthodologiques pour la formation d'experts médico-légaux dans chaque spécialité d'expert distincte qui devraient être ajoutées en tant que sujets de recherche distincts, au plan de recherche du ministère de la Justice de l'Ukraine. Il est précisé qu'une étude détaillée nécessite de déterminer la nécessité d'introduire dans le système de formation des experts légistes une composante telle que le mentorat.

Il a été souligné que l'amélioration de la réglementation juridique de la formation d'experts à l'étranger dans les institutions spécialisées compétentes et la coordination de ce domaine d'activité par le ministère auront un impact positif non seulement sur la qualité de la formation mais aussi sur l'acquisition d'une expérience internationale avec d'autres possibilités d'améliorer les techniques de prise d'empreintes digitales.

Mots-clés: expert dactyloscopiste, examen dactyloscopique, préparation, recyclage, formation avancée, actes juridiques normatifs.

\section{И. А. Петрова, О. В. Курдес}

ОСОБЕННОСТИ ПОДГОТОВКИ И ПОВЫШЕНИЯ КВАЛИФИКАЦИИ ЭКСПЕРТОВ-ДАКТИЛОСКОПИСТОВ

Целью статьи является выявление недостатков при подготовке, переподготовке и повышении квалификации экспертов-дактилоскопистов, определение научных основ совершенствования этого направления деятельности Анализ наработок отечественных ученых позволил установить, что единого унифицированного 


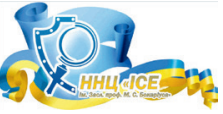

нормативно-правового акта, который регулирует подготовку, переподготовку и повышение квалификации судебного эксперта, независимо от ведомственной подчиненности, в Украине не существует.

Доказано, что действующая нормативно-правовая база профессиональной подготовки су дебно-экспертных кадров, в том числе экспертов-дактилоскопистов, системы Министерства юстиции Украины находится на стадии становления и развития требует дальнейшего реформирования. Считаем необходимым выделить из Положения о Центральной экспертно-квалификационной комиссии при Ми нистерстве юстиции Украины и аттестации судебных экспертов раздел «Порядок подготовки и стажировки специалистов», также разработать на его основе отдельный нормативно-правовой акт о порядке проведения профессиональной подготовки экспертов.

Особое внимание было уделено вопросу отсутствия методических рекомендаций по организации учебного процесса подготовки судебного эксперта, что негативно влияет на процесс обучения непосредственно на местах (в судебно-экспертных учреждениях). Установлено целесообразность разработки методических рекомендаций по подготовке судебных экспертов по каждой отдельной экспертной специальности, что предложено добавить, как отдельные темы НИР, в план научно-исследовательских работ Министерства юстиции Украины. Констатировано, что необходимым есть детальное исследование внедрения в систему подготовки судебно-экспертных кадров такой составляющей как наставничество.

Акцентировано, что совершенствование нормативно-правового регулирования прохождения обучения экспертов за рубежом в соответствующих экспертных учреждениях и координация данного направления деятельности Министерством окажет положительное влияние не только на качество обучения, но и на приобретение мирового опыта с последующей возможностью усовершенствования методик проведения дактилоскопических экспертиз.

Ключевые

слова: эк с пе р т - да к т л оскопис т, дактилоскопическая экспертиза, подготовка, переподготовка, повышение квалификации, нормативно-правовые акты.
Peculiarities of Training and Advanced Training

of Fingerprint Experts

training of the fingerprint expert, concludes that it is necessary to expand the range of his special knowledge. He believes that this work should be carried out comprehensively in several areas, namely:

- $\quad$ - conducting scientific seminars and practical classes by specialists

in the field of forensic examination according to research methods;

- $\quad$ - independent study of additional literature by experts;

- $\quad$ - obtaining consultations from specialists in the field of forensic examination 15 .

According to N. L. Komissarov, traditional forms of training: lectures and seminars in the training of forensic experts are ineffective because they do not provide a combination of all levels of information perception: visual, auditory and tactile. He offers to conduct professionally-oriented games as part of practical training ${ }^{16}$.

An example of successful training of persons, who intend to obtain the qualification of the forensic expert, retraining and advanced training of forensic experts is the creation of advanced training department (hereinafter referred to as Department) at National Scientific Center "Hon. Prof. M. S. Bokarius Forensic Science Institute" (hereinafter referred to as NSC "Hon. Prof. M. S. Bokarius FSI"), the main functions of which are training (internship) and advanced training of forensic experts as state specialized institutions and persons who are not employees of these institutions.

Employees of the Department have developed a system of assigning by order of the director of the institution to employees who intend to obtain the qualification of the forensic expert, experienced experts who have signs of mentoring. However, the problem of material incentives for the work of internship supervisors needs to be addressed at the level of the Ministry of Justice of Ukraine (hereinafter referred to as the Ministry). Also, there is a need to study the experience of NSC "Hon. Prof. M. S. Bokarius FSI" on conducting internal exams based on the results of theoretical and practical training courses with subsequent legal regulation by the Ministry.

At NSC "Hon. Prof. M. S. Bokarius FSI" an internship is performed in order to obtain (confirm) the qualification of the forensic expert from other state specialized institutions. In this regard, it is proposed to develop and approve a joint interdepartmental legal act, which will regulate the procedure for such training. According to the plan of improvement activities of the advanced training department of NSC "Hon. Prof. M. S. Bokarius FSI", in the near future it is planned to hold such events as:

- use forensic experts in the process of training in a new expert specialty of the institute of mentoring by developing an appropriate local legal act;

- development of guidelines for internships in structural units of NSC "Hon. Prof. M. S. Bokarius FSI" of persons who intend to obtain (confirm) the qualification of the forensic expert;

- development of the procedure for organizing independent training of persons undergoing training (internship) in order to obtain (confirm) the qualification of the forensic expert, and their introduction into the educational process;

- development of annually updated guidelines and lecture notes, containing general provisions and recent changes in legislation in the course Theoretical, organizational and procedural issues of forensic science;

- $\quad$ elaboration of the possibility of developing guidelines for training in a specific expert specialty;

- $\quad$ improving the learning process through the use of visual information (diagrams, tables, illustrations) through the introduction of presentations on specific learning topics.

E. B. Simakova - Yefremian and colleagues believe that the state's law enforcement and judicial systems are extremely interested in training highly qualified forensic experts taking into account both domestic and foreign

Бондарь М. Є. Удосконалення професійної підготовки експерта-почеркознавця 3 урахуванням розширення кола його спеціальних знань. Експертне забезпечення правосуддя:матер. міжнар. наук.-практ. конф. Сімферополь. КримНДІСЕ. 2006. С. 291

16 Коміссаров Н. Л. Особливості підготовки судових експертів для експертної служби MBC України. Експертне забезпечення правосуддя:матер. міжнар. наук.-практ. конф. Сімферополь. КримНДІСЕ. 2006. С. 297. 
experience $^{17}$. Their opinion that an effective form of international cooperation is the mutual internships of forensic experts and scientists in forensic institutions of other countries is interesting ${ }^{18}$. Supporting the position of scientists, we note that improving the legal regulation of experts training abroad in relevant expert institutions and coordination of this area of activity by the Ministry will have a positive impact not only on the quality of training but also on gaining international experience with further improvement of fingerprint analyses

The current training program (internship) for the expert specialty 4.6 Fingerprint analysis, approved by the Ministry of Justice of Ukraine, provides for the mastery of a theoretical course of study. At the same time, mastering the practical course needs improvement, namely: studying the possibility of mandatory mastering of the method of fingerprint analysis only in the laboratory. In this regard, it is considered appropriate in the training plans of experts to indicate the place of classes, the means of measuring equipment used, research equipment, consumables. In the absence of the necessary equipment and consumables in the research institution, it is necessary to determine the possibility of passing some classes in other research institutions that have such equipment and consumables.

CIt should be noted that the Regulations on the Central Expert Qualification Commission under the Ministry of Justice of Ukraine and certification of forensic experts provide for a minimum amount of training programs (internships), namely:

- у у разі присвоєння кваліфікації судового експерта - 40 - in case of qualification of the forensic expert - 40 academic hours (hereinafter referred to as the program No. 1);

- $\quad$ in the case of the first confirmation of the qualification of the forensic expert - 32 academic hours (hereinafter referred to as the program No. 2);

- in case of further confirmations of the qualification of a forensic expert - 24 academic hours (hereinafter referred to as the program No. 3$)^{19}$

However, the above programs are the same in content and differ only in the number of hours devoted to the educational process. A similar situation can be observed with regard to training programs in relevant expert specialties. This situation is unacceptable and needs to be improved.

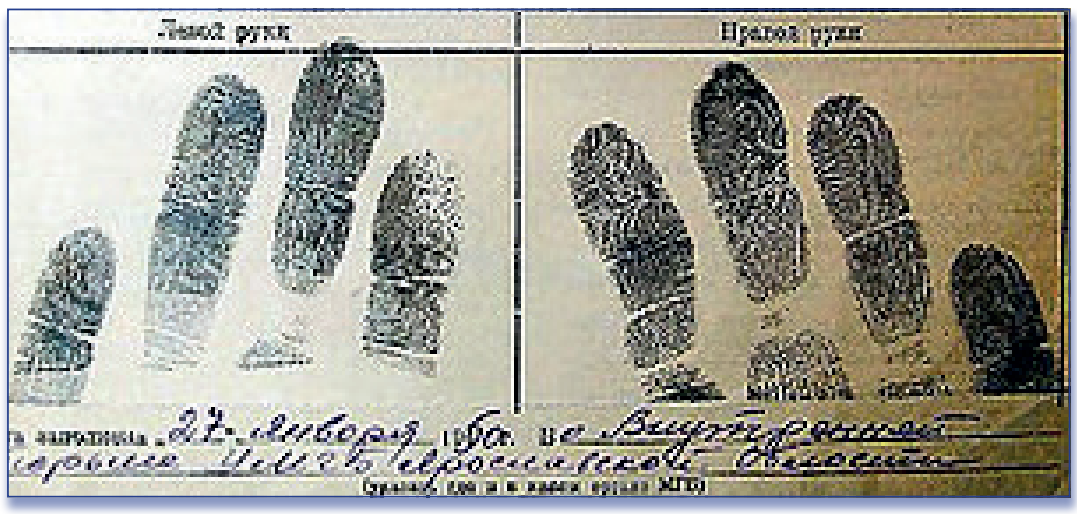

Figure 5. Fingerprintsk

17 Сімакова-Сфремян Е. Б., Дереча Л. М., М'ясоєдов В. В. Актуальні проблеми співробітництва з організаціями іноземних держав у сфері судово-експертної діяльності. Теорія та практика судової експертизи і криміналістики. Харків : Право, 2018. Вип. 18. С. 175. DOI https://doi. org/10.32353/khrife.2018.19

18 Там само. С. 177

19 Про затвердження Положення про Центральну експертно-кваліфікаційну комісію при Міністерстві юстиції України та атестацію судових експертів : Наказ Міністерства юстиції України від 03.03.2015 № 301/5. URL: https://zakon.rada.gov.ua/laws/card/z0249-15 (дата звернення 07.05.2021).

\section{Funding}

This research did not receive any specific grant from funding agencies in the public, commercial, or not-for-profit sectors.

\section{Disclaimer}

The funder had no role in the study design, data collection and analysis, decision to publish, or preparation of the manuscript.

\section{Contributors}

The authors contributed solely to the intellectual discussion underlying this paper, case-law exploration, writing and editing, and accept responsibility for the content and interpretation.

\section{Declaration of Competing} Interest

The authors declare that they have no conflict of interest. 
We also propose to distinguish between the concept of training (internship), which is defined in the Regulations on the Central Expert Qualification Commission under the Ministry of Justice of Ukraine and certification of forensic experts, and introduce the following procedure for training forensic experts:

- expert for the first time;

- additional training for forensic experts who intend to obtain additional qualification of forensic expert;

- advanced training for forensic experts who intend to confirm the qualification of a forensic expert.

Accordingly, a separate training program should be developed for each category of specialists, which will take into account their existing knowledge and experience of expert work.

At the same time, it is necessary to consider in more detail the methods of the fingerprint analysis, which are registered in the state Register of methods of forensic examinations. Thus, according to the Register, the following are registered in it

\begin{tabular}{|c|c|c|c|c|c|}
\hline & Вид експертизи & Назва методики & $\begin{array}{c}\text { Найменування } \\
\text { розробника } \\
\text { (спеціалізована } \\
\text { установа, інші) }\end{array}$ & Рік & $\begin{array}{c}\text { Дата } \\
\text { прийняття } \\
\text { рішення } \\
\text { про } \\
\text { державну } \\
\text { реєстрацію }\end{array}$ \\
\hline 4.6 .03 & $\begin{array}{l}\text { 4. Trace evidence } \\
\text { analysis } \\
\text { 4.6. Fingerprint } \\
\text { analysis }\end{array}$ & $\begin{array}{l}\text { Methodology of expert } \\
\text { assessment of identification } \\
\text { features during fingerprint } \\
\text { analysis }\end{array}$ & $\begin{array}{l}\text { SRI of the MIA of } \\
\text { the RSFSR }\end{array}$ & 1961 & 06.02 .2009 \\
\hline 4.6 .10 & $\begin{array}{l}\text { 4. Trace evidence } \\
\text { analysis } \\
\text { 4.6. Fingerprint } \\
\text { analysis }\end{array}$ & $\begin{array}{l}\text { Methodology of fingerprint } \\
\text { analysis }\end{array}$ & MIA & 1986 & 06.02 .2009 \\
\hline 4.6 .14 & $\begin{array}{l}\text { 4. Trace evidence } \\
\text { analysis } \\
\text { 4.6. Fingerprint } \\
\text { analysis }\end{array}$ & $\begin{array}{l}\text { Methodology of fingerprint } \\
\text { analysis }\end{array}$ & $\begin{array}{l}\text { SRFC of the MIA } \\
\text { of Ukraine }\end{array}$ & 2014 & 29.01 .2016 \\
\hline
\end{tabular}

According to the Register, among the three registered methods - two (registration codes 4.6.03 and 4.6.10) developed and may be considered obsolete. The methodology of fingerprint analysis (registration code 4.6.14) is the first and only method of fingerprint analysis, developed in an independent Ukraine by specialists of the Ministry of Internal Affairs of Ukraine. In our opinion, the issue of developing a common unified interdepartmental methodology of the fingerprint analysis by the fingerprint experts, taking into account the scientific achievements of all ministries and departments, as well as world experience, is urgent. The presence of such a technique would improve not only the quality of the fingerprint analysis, but also the practical training of the future fingerprint experts.

Conclusions. Therefore, current regulatory legal framework for professional training of forensic experts, in particular fingerprint experts, of the system of the Ministry of Justice of Ukraine is at the stage of formation and development and requires further reformation. It is necessary to highlight the section: Procedure for specialists' training and internship in the Regulations on the Central Expert Qualification Commission under the Ministry of Justice of Ukraine and Certification of Forensic Experts, and to develop a separate regulatory legal act regarding the procedure for advanced training.

It is also necessary to distinguish between the concepts of training (internship) and advanced training in the system of the Ministry of Justice of Ukraine, to study the possibility of introducing into the general system of training forensic experts such concepts as: initial training, additional training, self-training and in-service training. It is proved that a detailed study needs to 
determine the need to introduce into the system of training of forensic experts such a component as mentoring.

The creation of a scientific and methodological structural unit at the Ministry of Justice of Ukraine is urgent, the main functions of which should be: improvement and updating of the regulatory framework for the professional training of forensic personnel; methodical support of this direction of activity; coordination of the processes of education, training, retraining and advanced training. The program of special training of fingerprint experts should take into account the basic training time for practical mastering of the fingerprint analysis in laboratory conditions. It is proposed to add to the qualifying exam the practical mastering of the method with its delivery in the appropriate laboratory. It is proposed to add to the qualifying exam the practical mastering of the method with its delivery in the appropriate laboratory.

The method of the fingerprint analysis, revision of outdated research methods and development of a unified interdepartmental methodology taking into account the latest achievements of science and technology and the introduction of world experience also need to be unified.

\section{References}

Sukhomlyn, T. V. \& Yurchyk, T. V. (2019) Sudovo-daktyloskopichna ekspertyza u kryminal'nomu provadzhenni (Eng. Forensic fingerprint analysis in criminal proceedings). Zbirnyk naukovykh prats' Kharkivs'koho natsional'noho pedahohichnoho universytetu imeni H. S. Skovorody. Kharkiv. Pravo. V. 30. P. 104109 [in Ukrainian].

Pro sudovu ekspertyzu (Eng. On forensic examination): Zakon Ukrayiny vid 25.02.1994 r. № 4038-KHII (zi zminamy ta dopovnennyamy). Vidomosti Verkhovnoyi Rady Ukrayiny (VVR).1994. № 28. URL: https://zakon.rada.gov.ua/laws/show/4038-12 [in Ukrainian].

Tkachenko,N.M. (2018) Udoskonalennya profesiynoyi pidhotovky sudovohoeksperta-vazhlyvyy faktor rozvytku ekspertnoyi dydaktyky (Eng. Improving the professional training of a forensic expert is an important developmental factor of expert didactics). Teoriya ta praktyka sudovoyi ekspertyzy i kryminalistyky : zb. nauk. prats'. Kharkiv : Pravo. Vyp. 18. P. 203-214. DOI https://doi.org/10.32353/khrife.2018.22 [in Ukrainian].

Hasparyan. S. H. (2018) Shlyahy pidvyshchennya yakosti pidhotovky kadriv dlya sudovo-ekspertnykh ustanov Ministerstva yustytsiyi Ukrayiny (Eng. Ways to improve the quality of training of forensic institutions of the Ministry of Justice of Ukraine). Teoriya ta praktyka sudovoyi ekspertyzy i kryminalistyky : zb. nauk. prats'. Kharkiv : Pravo. Vyp. 18. P. 281-287. DOI https://doi.org/10.32353/ khrife.2018.30 [in Ukrainian].

Hasparyan. S. H. (2019) Mistse administratyvno-pravovykh norm u pravovomu rehulyuvanni kadrovoho zabezpechennya sudovo-ekspertnykh ustanov Ukrayiny (Eng. The place of administrative and legal norms in the legal regulation of staffing of forensic institutions of Ukraine). Teoriya ta praktyka sudovoyi ekspertyzy i kryminalistyky : zb. nauk. prats'. Kharkiv: Pravo. Vyp. 20. P. 175-188. DOI https:// doi.org/10.32353/khrife.2.2019.13 [in Ukrainian].

Solovey, O. V. (2019) Osoblyvosti profesiynoyi pidhotovky pratsivnykiv ekspertnoyi sluzhby Ministerstva vnutrishnikh sprav Ukrayiny (Eng. Peculiarities of professional training of employees of the Expert Service of the Ministry of Internal Affairs of Ukraine). Teoriya ta praktyka sudovoyi ekspertyzy i kryminalistyky : zb. nauk. prats'. Kharkiv: Pravo. Vyp. 20. S. 230-237. DOI https://doi.org/10.32353/ khrife.2.2019.17 [in Ukrainian].

Petrova, I. A. \& Sniher'ov, O. P. (2017) Formuvannya osobystosti suchasnoho sudovoho eksperta (Eng. ). Teoriya ta praktyka sudovoyi ekspertyzy i kryminalistyky: zb. nauk. prats'. Kharkiv: Pravo. Vyp. 17. P. 165-171. DOI https://doi.org/10.32353/ khrife.2017.20 [in Ukrainian].

Komaha, V. O. \& Strilets, H. O. \& Chernobay, L. M. (2006) Aktual'ni aspekty stosovno kadrovoyi pidhotovky sudovykh ekspertiv v Ukrayini (Eng. Topical aspects concerning personnel training of forensic experts in Ukraine). Ekspertne 
zabezpechennya pravosuddya:mater. mizhnar. nauk.-prakt. konf. Simferopol'. KrymNDISE. 2006. P. 291-296. [in Ukrainian].

Metodyka daktyloskopichnoyi ekspertyzy (Eng. Methods of dactyloscopic examination). Ekspertna spetsial'nist' 4.6 «Daktyloskopichni doslidzhennya» / [ukl. Zholtans'ka I. I., Kuznyetsov V. A., Shchavelyev A. V., Dymytrova YU. V., Kushnirenko N. V.]. Kyiv. DNDEKTS MVS Ukrayiny, 2014. 119 p. [in Ukrainian].

Polozhennya pro Tsentral'nu ekspertno-kvalifikatsiynu komisiyu pry Ministerstvi yustytsiyi Ukrayiny ta atestatsiyu sudovykh ekspertiv (Eng. Regulations on the Central Expert Qualification Commission at the Ministry of Justice of Ukraine and certification of forensic experts). Zatv. Nakazom Ministerstva yustytsiyi Ukrayiny vid 03.03.2015 № 301/5. (zi zminamy ta dopovnennyamy). URL: https://zakon.rada. gov.ua/laws/card/z0249-15 [in Ukrainian].

Bondar, M. YE. (2006) Udoskonalennya profesiynoyi pidhotovky ekspertapocherkoznavtsya $\mathrm{z}$ urakhuvannyam rozshyrennya kola yoho spetsial'nykh znan' (Eng. Improving the professional training of a handwriting expert, taking into account the expansion of his range of special knowledge). Ekspertne zabezpechennya pravosuddya: mater. mizhnar. nauk.-prakt. konf. Simferopol'. KrymNDISE. P. 286-291. [in Ukrainian].

Komisarov, N. L. (2006) Osoblyvosti pidhotovky sudovykh ekspertiv dlya ekspertnoyi sluzhby MVS Ukrayiny (Eng. Peculiarities of training forensic experts for the Expert Service of the Ministry of Internal Affairs of Ukraine). Ekspertne zabezpechennya pravosuddya: mater. mizhnar. nauk.-prakt. konf. Simferopol'. KrymNDISE. 2006. P. 296-299. [in Ukrainian].

Simakova-Yefremian, E. B. \& Derecha, L. M. \& M'yasoyedov, V. V. (2018) Aktual'ni problemy spivrobitnytstva z orhanizatsiyamy inozemnykh derzhav u sferi sudovoekspertnoyi diyal'nosti (Eng. Tipical problems of cooperation with organizations of foreign states in the field of forensic activity). Teoriya ta praktyka sudovoyi ekspertyzy i kryminalistyky. Kharkiv : Pravo. Vyp. 18. P. 175-188.DOI https://doi. org/10.32353/khrife.2018.19 [in Ukrainian].

Received by Editorial Board: 26.05.2021

Suggested Citation:

Petrova, I. A., Kurdes, O. B. (2021). Peculiarities of Training and Advanced Training of Fingerprint Experts. Archives of Criminology and Forensic Sciences. 1(3). 65-71. DOI: https://doi.org/10.32353/acfs.3.2021.07 